\title{
Hygrocybe salicis-herbaceae (Agaricomycetes, Hygrophoraceae): an arctic-alpine species new to the South-Eastern Carpathians (Romania)
}

\author{
ANNA RONIKIER \\ Department of Mycology, W. Szafer Institute of Botany, Polish Academy of Sciences \\ Lubicz 46, PL-31-512 Kraków, a.ronikier@botany.pl
}

Ronikier A.: Hygrocybe salicis-herbaceae (Agaricomycetes, Hygrophoraceae): an arctic-alpine species new to the South-Eastern Carpathians (Romania). Acta Mycol. 45 (1): 37-43, 2010.

New localities of Hygrocybe salicis-herbaceae were observed during the research on the fungi of the alpine zone in the Carpathians. This is the first record of this arctic-alpine fungus in the South-Eastern Carpathians. Macro- and micromorphological characters of the Carpathian collections are compared with the descriptions from other regions. A revision of literature data indicates that the sites in the Parâng Mts reported here are the only known localities of the species from the entire Carpathian range.

Key words: Parâng Mts, biogeography, alpine belt, Southern Carpathians, arctic-alpine element

\section{INTRODUCTION}

Hygrocybe salicis-herbaceae Kühner is one of the arctic-alpine representatives of the genus. It belongs to the section Coccineae Fayod, subsection Coccineae (Bataille) Singer, and is characterized by an orange-reddish lubricous pileus, adnate lamellae, a reddish to yellow lubricous or moist stipe and a distinctly acrid or bitter taste (Boertmann 2000). The fungus is known from high-mountain belts of the European mountains as well as from subarctic and arctic regions (Boertmann 2000, 2008). Hygrocybe salicis-herbaceae was recorded at a few new localities during the research on the fungi of the alpine belt of the Southern Carpathians. This is the first report of the species from the South-Eastern Carpathians. The aim of this paper is to present the new data, give a detailed description of the SouthernCarpathian collections and compare them with the descriptions from other regions available in the literature. The distribution of the species in the Carpathian chain is also revised. 


\section{MATERIAL AND METHODS}

The material was collected in August 2009 at a few localities in the Parâng Mts. in the Southern Carpathians (Romania). Colours were described using field notes of fresh collections with colour annotations based on Kornerup and Wanscher (1965).

All measurements were made in 5\% KOH or Congo Red under an oil immersion lens. The spores for measurements ( 20 per collection) were taken from a natural spore deposit present at stipe apex or only mature spores floating in the preparation were measured. The average and the quotients of the length and width of spores $(\mathrm{Q})$ as well as average quotients $\left(\mathrm{Q}_{\mathrm{av}}\right)$ were calculated. Drawings of microcharacters were made with the aid of a drawing tube (Nikon Y-IDT). Specimens are deposited in the Herbarium of the W. Szafer Institute of Botany, Polish Academy of Sciences, Kraków (KRAM).

\section{RESULTS}

Hygrocybe salicis-herbaceae Kühner

Figs 1-3

Pileus 10-25 mm, convex to conico-convex, reddish-orange, orange-yellow, slightly darker at centre and paler toward margin (6A8, 5A6, 5A7-8, 4A7-8, 6B-8) or paler at centre (on drying), not translucently striate, surface lubricous and moist
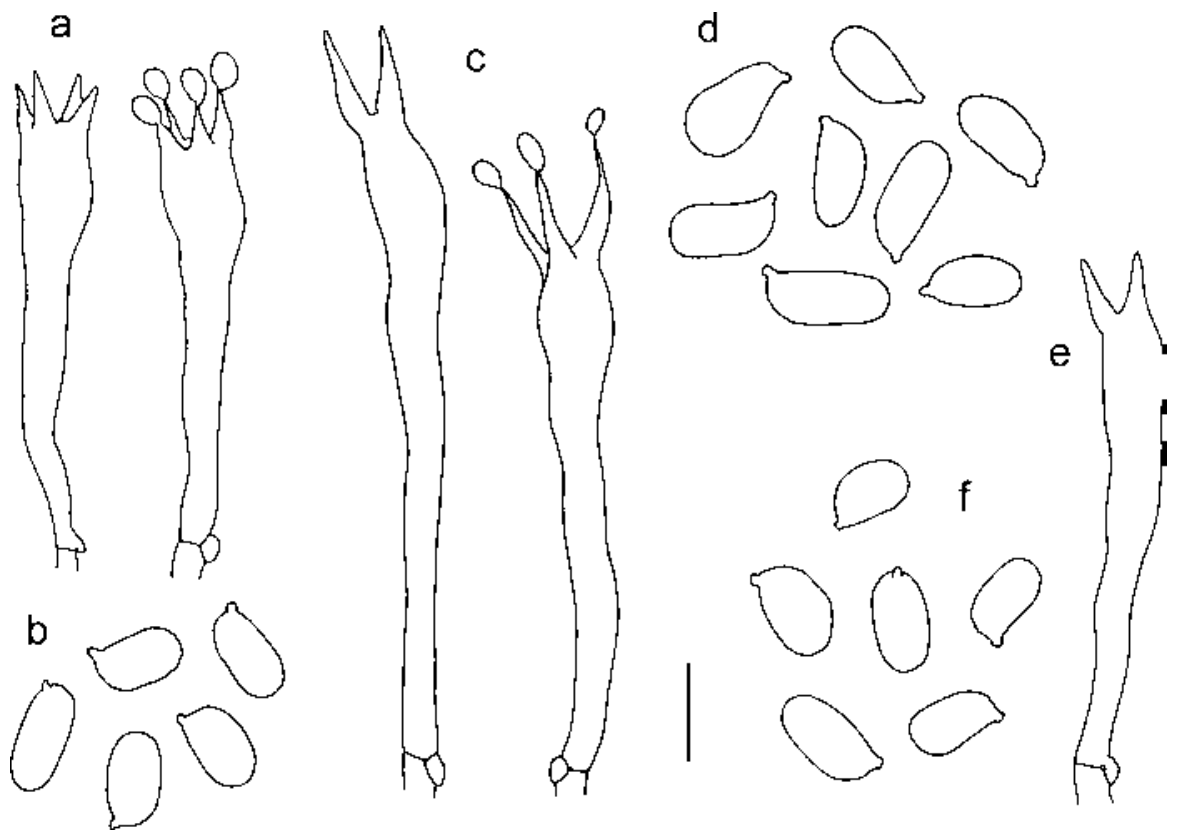

Fig. 1. Basidia and spores of Hygrocybe salicis-herbaceae from the localities in the Parâng Mts: a, b - KRAM F-48033; c, d - KRAM F-48031; e, f - KRAM F-48032. Scale bar $=10 \mu \mathrm{m}$. 
a
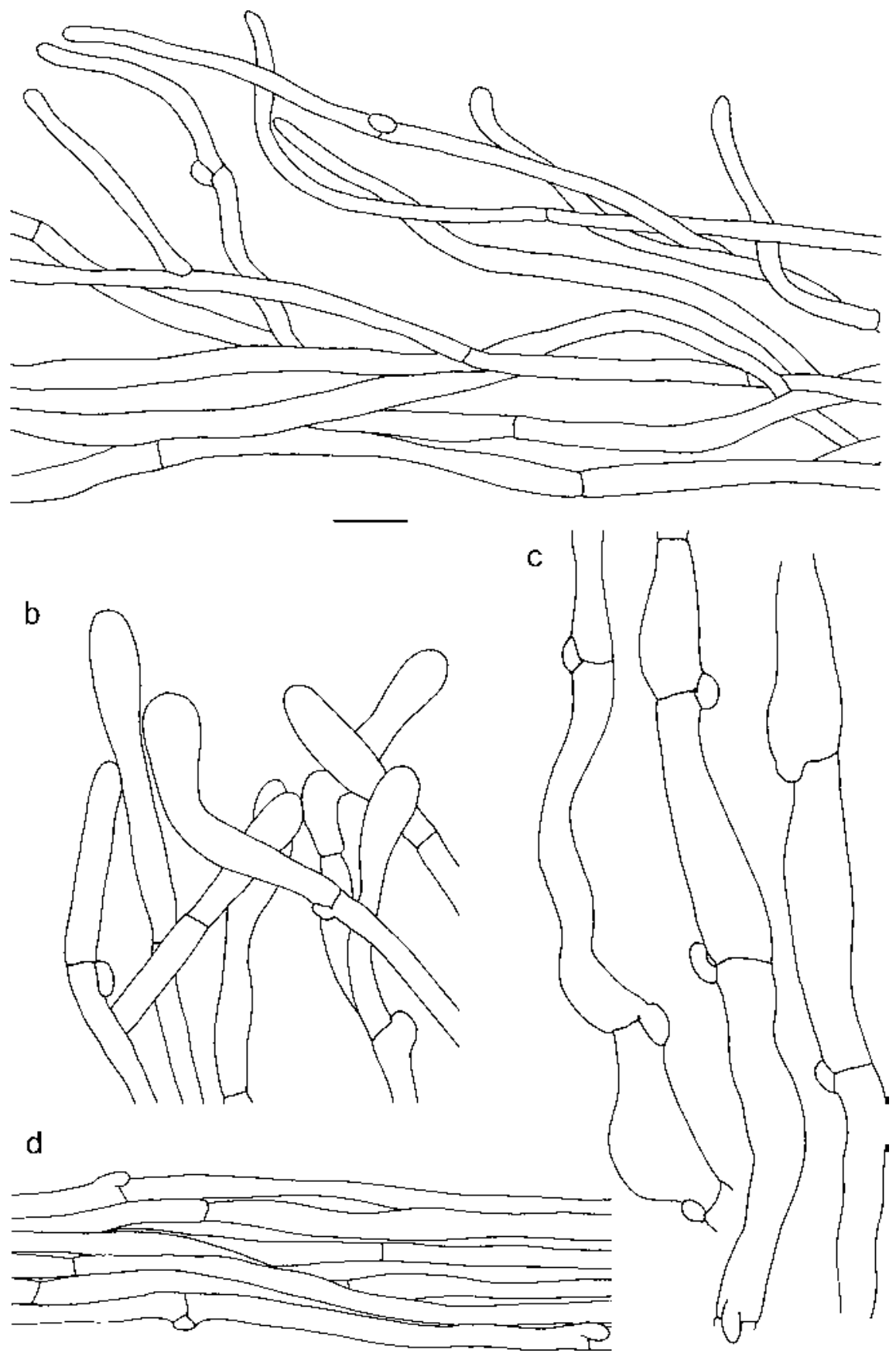

Fig. 2. Micromorphological characters of Hygrocybe salicis-herbaceae from the localities in the Parâng Mts, KRAM F-48031: a - pileipellis of a mature basidiome; $b$ - pileipellis of a young basidiome; $\mathrm{c}$ - hymenophoral trama; $\mathrm{d}$ - stipitipellis. Scale bar $=10 \mu \mathrm{m}$. 
or slightly sticky in young basidiomata, not glutinous, later dry. Lamellae distant, adnate to slightly emarginate, 2-3 mm wide, pale yellow to dark yellow (2A4, 3A4-6, 4A6-7) with paler, yellowish edge, sometimes venose. Stipe $12-25 \times 3-6 \mu \mathrm{m}$, cylindrical or slightly wider at base, reddish-orange, orange-yellow (6A8, 5A8, 4A7-8), surface dry and smooth, base yellow to whitish (Fig. 3). Flesh pale yellow (2A5), orange-yellow at pileipellis and stipitipellis. Smell none, taste first mild, then very acrid (after several seconds of chewing).

Spores broadly ellipsoid, ellipsoid-cylindrical, a few slightly swollen at base (7-)8-11.5(-14) × (4.5-)5-6.5(-7) $\mu \mathrm{m}$, av. $9.8 \times 5.7 \mu \mathrm{m}, \mathrm{Q}=1.3-2.8, \mathrm{Q}_{\mathrm{av}}=1.7$ (Figs $1 \mathrm{~b}$, d, f). Basidia 49-66 × 8-10 $\mu \mathrm{m}$, (1-)2-, 3- or 4-spored, clamped (Figs 1a, c, e). Hymenophoral trama subregular made up of short elements $15-75 \times(4.5-) 7-13(-14)$ $\mu \mathrm{m}$ (Fig. 2c). Pileipellis an ixotrichoderm to ixocutis, epicutis built up of cylindrical hyphae 2-3.5 $\mu \mathrm{m}$ in diameter; terminal elements cylindrical or clavate, and apically swollen up to $7.5 \mu \mathrm{m}$ wide (Figs $2 \mathrm{a}, \mathrm{b}$ ). Stipitipellis a cutis built up of cylindrical hyphae 2.5-4 $\mu \mathrm{m}$ in diameter (Fig. 2d).

Specimens eXamined. Romania, Parâng Mts., E slopes of Mt. Vârful Slivei, N 45²1'07”, E 2332'04”, alt. $2400 \mathrm{~m}$, high mountain vegetation with Salix herbacea, Primula minima and Soldanella pusilla, 26 Aug. 2009, leg. A. Ronikier, M. Ronikier, KRAM F-48031; Parâng Mts., Şaua Gruiului pass, N 45²0'21", E23 32'41", alt. 2380 m, high mountain vegetation with Salix herbacea and grasses, 26 Aug. 2009, leg. A. Ronikier, M. Ronikier, KRAM F-48032; Parâng Mts., E slopes of Mt. Vârful Parângul Mare, N 4520'31", E 2332'38", alt. $2250 \mathrm{~m}$, high mountain vegetation with Salix herbacea, Polygonum viviparum and mosses, 25 Aug. 2009, leg. A. Ronikier, M. Ronikier, KRAM F-48033.

\section{DISCUSSION}

Macroscopic characters are generally uniform in the three Southern Carpathian collections of Hygrocybe salicis-herbaceae but the specimens differ slightly by the colour of basidiomes. One collection is reddish-orange (Fig. 3b), while the other two are paler, orange-yellow (Fig. 3a). The differences, however, seem to be within the range of the species (see Boertmann 2000). The three collections also differ in the spore size and the number of sterigmata on basidia. These characters are usually interrelated in agarics and 2-spored basidia produce slightly larger spores than 4-spored basidia. Kühner (1977) also observed differences in spore sizes between his collections of Hygrocybe salicis-herbaceae from the Alps where basidiomata with 4-spored basidia had smaller spores: 7-9.5 $\times 3.5-5 \mu \mathrm{m}$ and 2-spored specimens - larger spores: 9.5-10.5(-11.7) $\times 5(6.5) \mu \mathrm{m}$, and 8-11 $\times$ 4.7-6.5 $\mu \mathrm{m}$. One of the new Carpathian collections (KRAM F-48033) is characterized by having 4-spored basidia and smaller spores: 8-10(-11) $\times 4.5-6 \mu \mathrm{m}$, av. $9.6 \times 5.6 \mu \mathrm{m}$, $\mathrm{Q}=1.5-2.0, \mathrm{Q}_{\mathrm{av}}=1.8$ (Figs $\left.1 \mathrm{a}, \mathrm{b}\right)$, while the other two have predominantly 2-spored basidia. The spores of the first of them (KRAM F-48031) are larger: 9-12(-14) $\times$ 5-7 $\mu \mathrm{m}$, av. $10.9 \times 5.8 \mu \mathrm{m}, \mathrm{Q}=1.5-2.8, \mathrm{Q}_{\mathrm{av}}=1.9$ (Fig. 1d), while the spores of the other (KRAM F-48032) are slightly smaller (shorter): (7-)8-10(-11) $\times 4.5-7 \mu \mathrm{m}$, av. $8.7 \times 5.6 \mu \mathrm{m}, \mathrm{Q}=1.3-1.8, \mathrm{Q}_{\mathrm{av}}=1.5$ (Fig. 1f). Two-spored basidia predominated in these two collections, but 3- and 4-spored basidia were also present (Figs 1c, e). Smaller spores originating from one of the predominantly 2 -spored collections 

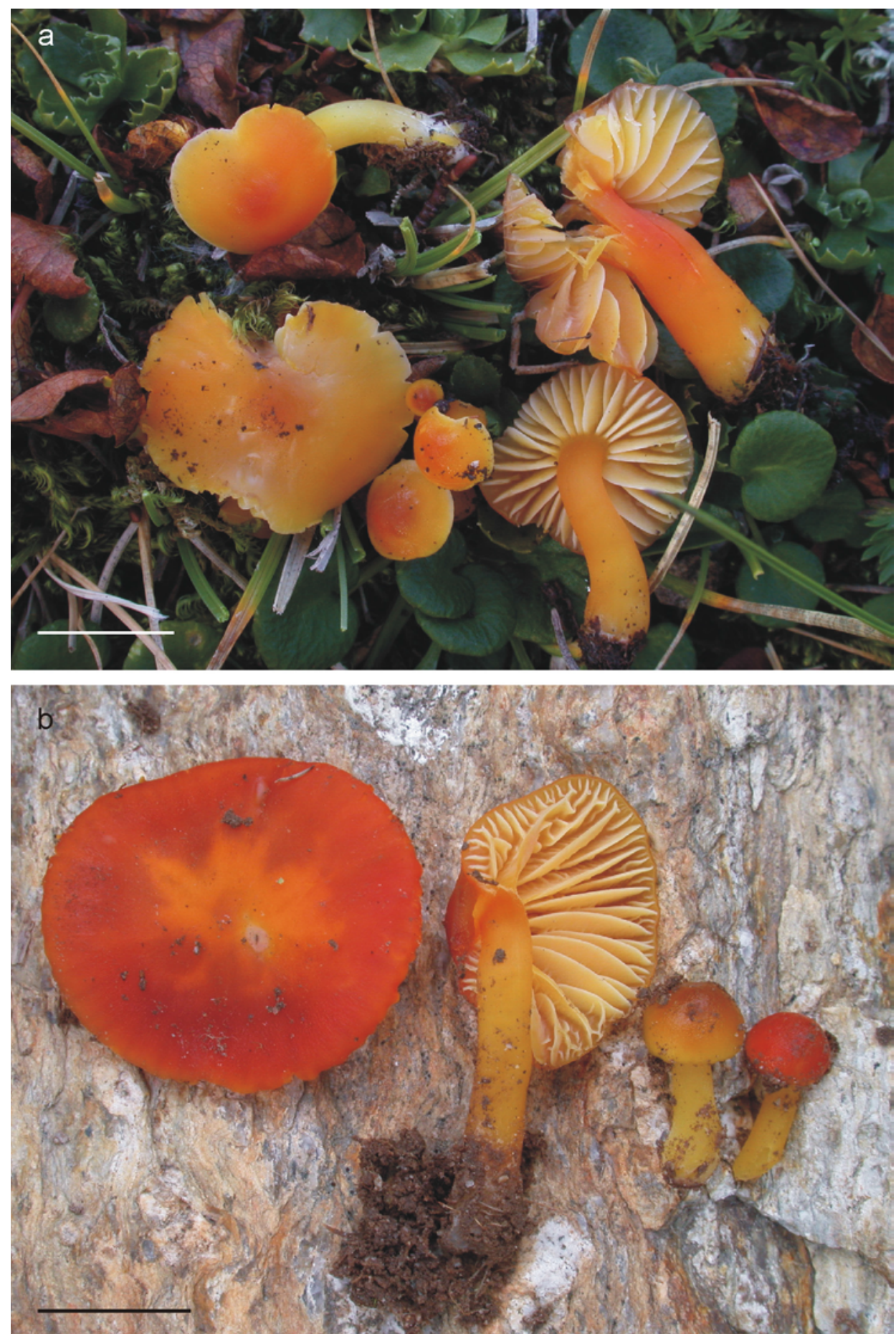

Fig. 3. Basidiomata of Hygrocybe salicis-herbaceae from the localities in the Parâng Mts: a - KRAM F-48031; b - KRAM F-48032. Scale bar $=10 \mathrm{~mm}$. 


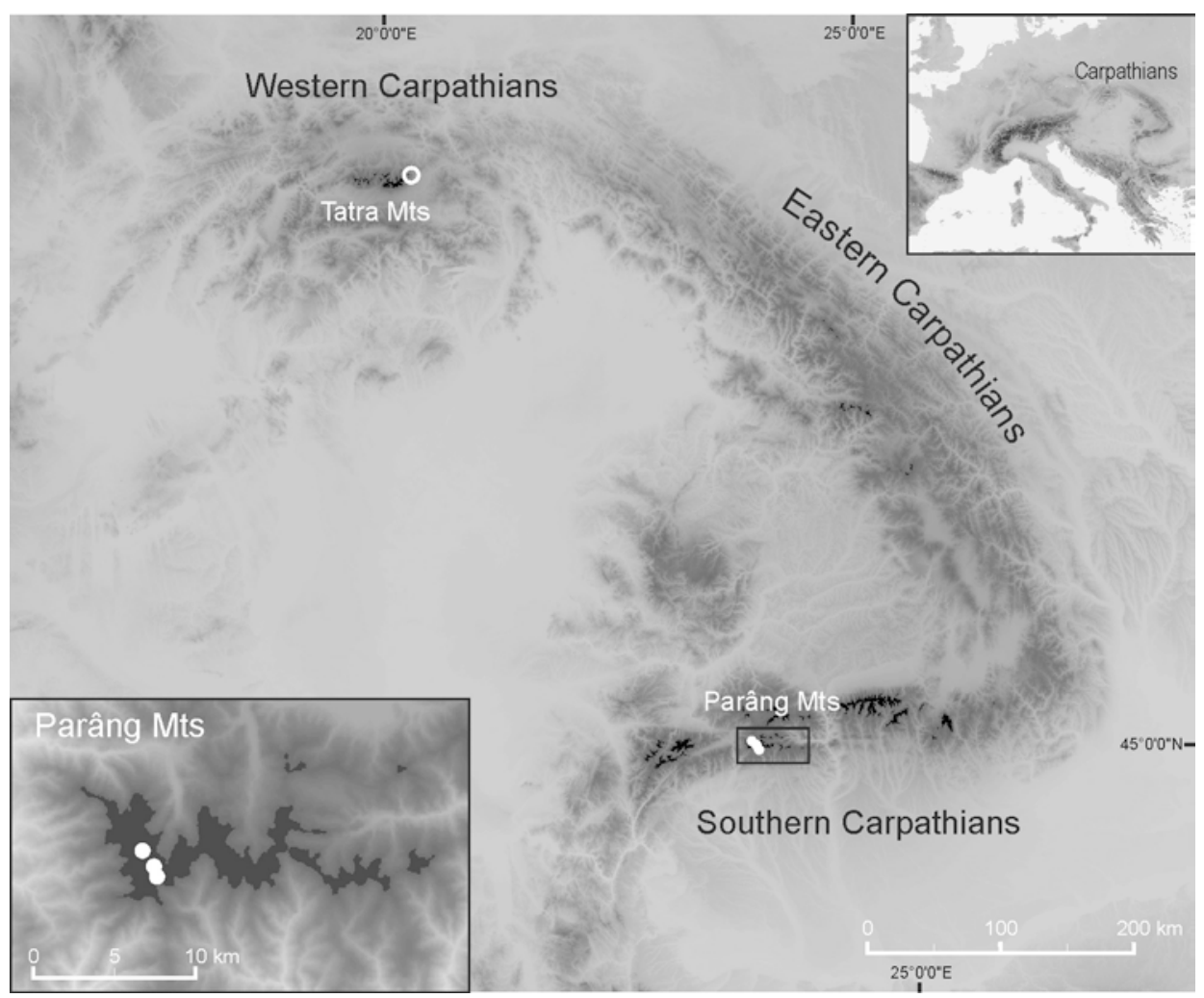

Fig. 4. The distribution of Hygrocybe salicis-herbaceae in the Carpathians.

White circles - certain localities, empty circle - uncertain locality (see explanation in the text). Upper right inset - location of the Carpathian massif in Central Europe. Lower left inset localities of $H$. salicis-herbaceae in the Parâng Mts, dark grey area - the alpine belt. 
may be explained by the fact that 4- and 3-spored basidia can produce more spores than 2-spored basidia. In general, spore size (from predominantly 4-spored basidia) given in other available descriptions of Hygrocybe salicis-herbaceae (Candusso 1997; Vila et al. 1998; Boertmann 2000, 2008; Hausknecht et al. 2003; Borgen, Arnolds 2004; Gulden 2005) is smaller than in the collections described here, $(6.5-) 8-9(-11) \times(3.5) 4.5-5.5(-7) \mu \mathrm{m}$ on average. It seems that 2-spored specimens with slightly larger spores are less frequent in the species.

Hygrocybe salicis-herbaceae has been reported from the Alps (Kühner 1977; Kühner, Lamoure 1986; Hausknecht et al. 2003; Jamoni 2006), the Norwegian mountains (Boertmann 2000; Gulden 2005), Finland (Candusso 1997), the Pyrenees (Vila et al. 1998; Corriol 2008), Greenland (Borgen, Arnolds 2004; Borgen 2006) and the Tatra Mts. in the Western Carpathians (Kautmanová 1998; Škubla 1998, but see comment below). The fungus is most frequently recorded in snowbeds with Salix herbacea. This type of vegetation usually occurs on poor, acidic soils (Lauber, Wagner 2001; Dúbravcova 2007). The three new Southern Carpathian collections of the species were also observed on granitic (acidic) bedrock, in nutrient-poor vegetation with $S$. herbacea. However, it seems that the fungus is not strictly associated with snowbed vegetation and its co-occurrence with $S$. herbacea may be due to similar ecological preferences toward nutrient-poor soils. The fungus was reported from Finland and Greenland at localities without S. herbacea observed nearby (Candusso 1997; Borgen, Arnolds 2004). The soil was most probably acidic at the Finnish locality as Sphagnum was growing there (Candusso 1997). Also in Greenland the fungus was always collected on acidic soils (T. Borgen, pers. comm.).

There is one report of Hygrocybe salicis-herbaceae from a calcareous massif in the Tatra Mts. (Kautmanová 1998; Škubla 1998). Although the description provided matches the characteristics of the species quite well, this record seems to be doubtful in my opinion. As mentioned above, the species has never been reported from calcareous soils and prefers nutrient-poor sites mostly with Salix herbacea. In the Tatra Mts., it was recorded near Salix reticulata (not mentioned in the text, but depicted in the drawing; Kautmanová 1998), which never occurs on acidic soils (e.g., Lauber, Wagner 2001). The pileus surface of $H$. salicis-herbaceae is usually described as lubricous, glabrous or even initially viscid (Kühner 1977; Candusso 1997; Boertmann 2000; Borgen, Arnolds 2004) and only finely nodulose or veined (Boertmann 2000). Kautmanová (1998) also describes the pileus surface as smooth, shining and lubricous: "hladký, lesklý a slizký", but the pileus surface seems to be minutely squamulose in the drawing included. Unfortunately, the collection from the Tatra Mts. was not available to me for study. Until the specimen is revised, the locality of $H$. salicis-herbaceae in the Tatra Mts. must be regarded as doubtful.

Based on the new data presented here, Hygrocybe salicis-herbaceae can be added to the list of the arctic-alpine species known from the Southern Carpathians, and the certain Carpathian records of it are localized only in the Parâng Mts. (Fig. 4). There are a few other species of the genus Hygrocybe that can be considered arctic-alpine. One of them, H. glacialis Borgen \& Senn-Irlet (Borgen, Senn-Irlet 1995), can be found in similar, nutrient-poor habitats. It differs from $H$. salicis-herbaceae by, for instance, a mild taste, squamulose pileus surface and pileipellis in the form of dry 
trichoderm to dry cutis. Hygrocybe glacialis has not been recorded in the Carpathians so far. Apart from arctic-alpine fungi, more ubiquitous species also occur in the alpine belt and are sometimes very common. $H$. conica is the most common species of Hygrocybe in the alpine belt of the Carpathians (Pilát 1969; Wojewoda 1996; Ronikier 2008); other species recorded here are: H. calciphila Arnolds, H. chlorophana (Fr.: Fr.) Wünsche, H. laeta (Pers.: Fr.) P. Kumm., H. miniata (Fr.: Fr.) P. Kumm., H. mucronella (Fr.) P. Karst., H. nitrata (Pers.) Wünsche, H. psittacina (Schaeff.: Fr.) P. Kumm., H. turunda (Fr.: Fr.) P. Karst. and H. virginea (Wulfen: Fr.) P.D. Orton (Kubička 1964; Pilát 1969; Bujakiewicz 1993, 1996, 2004; Ronikier 2008; Ronikier, Borgen 2010). Additionally, Nespiak (1960) invalidly described (type not indicated, see Art. 37.1 of ICBN; McNeill et al. 2006) 'Hygrocybe tatrensis' from the alpine belt of the Tatra Mts. According to the description, the specimens had a citrine yellow conical pileus, blackening flesh, and were characterized by a pineapple smell. Apart from the characteristic smell, all characters of 'Hygrocybe tatrensis' seem to be similar to those of $H$. conica s.l. and it may represent this species.

There are ten Hygrocybe species known from the alpine belt of the Carpathinas, of which $H$. turunda and, it seems, also $H$. salicis-herbaceae are known only from the South-Eastern part of the range.

Acknowledgements. I am greatly indebted to Michał Ronikier (Kraków) for his help in collecting and describing fungi in the field. Torbjørn Borgen (Copenhagen) is thanked for critical comments on the manuscript and Joanna Kazik (Łódź) for improving the English. This work is the result of studies carried out within projects 2 P04C 08630 and N N303 308237 financed by the Polish Ministry of Science and Higher Education.

\section{REFERENCES}

Boertmann D. 2000. The genus Hygrocybe. Fungi of Northern Europe 1. $3^{\text {rd }}$ edn. Danish Mycological Society, Copenhagen.

Boertmann D. 2008. Hygrocybe (Fr.) P. Kumm. (In:) H. Knudsen, J. Vesterholt (eds). Funga Nordica. Agaricoid, boletoid and cyphelloid genera.: 194-212. Nordsvamp, Copenhagen.

Borgen T. 2006. Distribution of selected basidiomycetes in oceanic dwarf-scrub heaths in the Paamiut area, low arctic South Greenland. Meddel. Grønland, Biosci. 56: 25-36.

Borgen, T., Arnolds E. 2004. Taxonomy, ecology and distribution of Hygrocybe (Fr.) P. Kumm. and $\mathrm{Ca}$ marophyllopsis Herink (Fungi, Basidiomycota, Hygrocybeae) in Greenland. Meddel. Grønland, Biosci. 54: 1-68.

Borgen T., Senn-Irlet B. 1995. Hygrocybe glacialis spec. nov. and notes on subsection Squamulosae based on collections from Switzerland. Doc. Mycol. 25 (98-100): 91-102.

Bujakiewicz A. 1993. Fungi of the alpine and subalpine zones of the Babia Góra massif. (In:) D. N. Pegler, L. Boddy, B. Ing, P. Kirk (eds). Fungi of Europe: Investigation, Recording and Conservation: 115-120. Royal Botanic Gardens, Kew.

Bujakiewicz A. 1996. Grzyby (Macromycetes) Babiej Góry na tle zróżnicowania roślinności. Zeszyty Naukowe PŁ - Inżynieria Włókiennicza i Ochrona Środowiska 40 (12): 33-40.

Bujakiewicz A. 2004. Grzyby wielkoowocnikowe Babiogórskiego Parku Narodowego. (In:) B. W. Wołoszyn, A. Jaworski, J. Szwagrzyk (eds). Babiogórski Park Narodowy. Monografia Przyrodnicza: 215-257. BgPN, Komitet Ochrony Przyrody PAN, Wydawnictwo i Drukarnia Towarzystwa Słowaków w Polsce.

Candusso M. 1997. Hygrophorus s.l. Fungi Europaei 6. Libreria Basso, Alassio.

Corriol G. 2008. Checklist of the Pyrenean alpine-stage macrofungi. Sommerfeltia 31: 29-99.

Dúbravcova Z. 2007. Salicetea herbaceae (In:) J. Kliment, M. Valahovič (eds). Rastlinné spoločenstvá Slovenska. 4. Vysokohorská vegetácia.: 253-281. Veda, Bratislava. 
Gulden G. 2005. A preliminary guide to the macromycetes in the Finse area, Hardangervidda, Norway. Draft presented at ISAM VII, Oslo.

Hausknecht A., Krisai-Greilhuber I., Jaklitsch W. 2003. Rezente Pilzfunde aus Osttirol. Österreichische Zeitschrift für Pilzkunde 12: 153-192.

Jamoni P. G. 2006. Catalogo sistematico, ecologico e ragionato dei macromiceti della zona alpina (e dell'Alnus viridis, con particolare riferimento all'area del Monte Rosa). Funghi e Ambiente 100: $1-150$.

Kautmanová I. 1998. Hygrocybe salicis-herbaceae Kühner - jedna z najmenších lúčnic. Spravodajca Slovenských Mykológov 6 (21/22): 14-15.

Kornerup A., Wanscher J. H. 1965. Farver i Farver [Methuen Handbook of Colour]. Politikens Forlag, København.

Kubička J. 1964. Výskyt mapovaných druhů hub v Tatrách. Česká Mykol. 18 (4): 221-225.

Kühner R. 1977. Agaricales de la zone alpine. Genre Hygrocybe (Fries) Kummer (suite et fin). Bull. Soc. Mycol. France 93 (1): 53-115.

Kühner R., Lamoure D. 1986. Catalogue des Agaricales (Basidiomycètes) de la zone alpine du Parc National de la Vanoise et des régions limitrophes. Trav. sci. Parc nat. Vanoise 15: 103-187.

Lauber K., Wagner G. 2001. Flora Helvetica. Flore illustrée de Suisse. Editions Paul Haupt, Berne-Stuttgart-Vienne.

McNeill J., Barrie F. R., Burdet H. M., Demoulin V., Hawksworth D. L., Marhold K., Nicolson D. H., Prado J., Silva P. C., Skog J. E., Wiersema J. H., Turland N. J. (eds). 2006. International Code of Botanical Nomenclature (Vienna Code). Adopted by the Seventeenth International Botanical Congress Vienna, Austria, July 2005. Regnum Vegetabile 146. A.R.G. Gantner.

Nespiak A. 1960. Notatki mikologiczne z Tatr. Fragm. Flor. Geobot. 6 (4): 709-724.

Pilát A. 1969. Houby Československa ve svém životním prostředí. Československá Akademia Věd, Praha.

Ronikier A. 2008. Contribution to the biogeography of arctic-alpine fungi - first records in the Southern Carpathians (Romania). Sommerfeltia 31: 191-211.

Ronikier A., Borgen T. 2010. Notes on Hygrocybe subsection Squamulosae from Poland. Polish Bot. J. 55(1): 209-215.

Škubla P. 1998. Príspevok k mykoflóre Belianskych Tatier. Spravodajca Slovenských Mykológov 6 (21-22): $51-55$.

Vila, J., Llistosella, J., Llimona, X. 1998. Contributió al coneixement dels fongs de l'estatge alpí dels Pirineus de Catalunya. II. Revista Catalana Micol. 21: 93-113.

Wojewoda W. 1996. Grzyby wielkoowocnikowe. (In:) Z. Mirek (ed). Przyroda Tatrzańskiego Parku Narodowego: 379-392. Tatrzański Park Narodowy, Kraków-Zakopane.

\section{Hygrocybe salicis-herbaceae (Agaricomycetes, Hygrophoraceae): arktyczno-alpejski gatunek nowy dla Karpat Południowo-Wschodnich (Rumunia)}

\section{Streszczenie}

W trakcie badań poświęconych grzybom piętra alpejskiego Karpat, znaleziono trzy nowe stanowiska Hygrocybe salicis-herbaceae zlokalizowane w górach Parâng w Karpatach Południowych (Rumunia). Jest to pierwsze doniesienie na temat występowania tego gatunku w Karpatach Południowo-Wschodnich. W niniejszej pracy przedstawiono okazy z nowych stanowisk, opisano i zilustrowano ich cechy makro- i mikromorfologiczne oraz porównano $\mathrm{z}$ opisami kolekcji z innych regionów dostępnymi w literaturze. Analiza danych z literatury wykazała, że jedyne znane dotychczas karpackie stanowisko pochodzące z Tatr Bielskich na Słowacji jest wątpliwe. Tym samym prezentowane w niniejszej pracy stanowiska Hygrocybe salicis-herbaceae są jedynymi pewnymi notowaniami tego gatunku w Karpatach. 